\title{
Sensory quality of scab-resistant apple cultivars
}

\author{
B.F. Kühn *, A.K. Thybo \\ Department of Horticulture, Danish Institute of Agricultural Sciences, Kirstinebjergvej 12, DK-5792 Aarslev, Denmark
}

Received 30 August 2000; accepted 11 January 2001

\begin{abstract}
Twenty-two scab-resistant apple cultivars were harvested in autumn 1999 and evaluated for sensory quality the following October, November and December. Multivariate analysis was effective in describing the complex relationships and variability among the numerous attributes used to characterise apple quality. Crispness, mealiness, skin toughness, apple flavour, sweetness, unripe flavour and overripe flavour were informative attributes describing the variation in the sensory quality. Texture attributes, apple flavour and overripe flavour were affected by storage. Extended storage resulted in an increase in mealiness and overripe flavour and a decrease in crispness, juiciness and apple flavour. Many potential scab-resistant cultivars were suitable for consumption in October: 'Dayton', 'Primicia', 'Retina' and 'Realka'; in November: 'Merlijn', 'Saturn', 'Initial', 'Realka', 'Rajka' and 'Rubinola'; and in December: 'Otava', 'Ecolette', 'Rajka', 'Rubinola', 'Delorina', 'Initial' and 'Resista' and 'Topaz'. This study gives a sensory characterisation of scab-resistant cultivars as an indicator of suitability for commercial growing and marketing of low-input apple cultivars. (C) 2001 Elsevier Science B.V. All rights reserved.
\end{abstract}

Keywords: Apple; Multivariate statistics; Principal-component analysis; Scab-resistant cultivars; Sensory quality; Storage

\section{Introduction}

The breeding of apples resistant to scab started 60 years ago as a genetically based strategy for control of this major fungal pathogen (Crosby et al., 1992), and numerous breeding programmes have been initiated. Scab-resistant cultivars give growers an opportunity to reduce disease control costs, lessen the risk of environmental contamination associated with fungicide applications, and meet consumer demands for reduced pesticide

\footnotetext{
* Corresponding author. Tel.: +45-63904343; fax: +4593904396.

E-mail address: birka.kuehn@agrsci.dk (B.F. Kühn).
}

residue on produce. The first scab-resistant cultivar was introduced in 1967 (Crosby et al., 1992). Although more than 48 cultivars were released world-wide in the period 1970-1990 (Crosby et al., 1992), growers have been slow to plant them. One reason might be uncertainty of consumer acceptance; consumers consider taste and quality to be important attributes when purchasing apples (Greene, 1998).

Previously, the sensory quality of the scab-resistant apple cultivars was often determined as eating quality using very few descriptors (Stehr, 1997; Kellerhals et al., 1998; Zimmer, 1999) or was determined for cultivars of little interest to- 
day (Durner et al., 1992; Granger et al., 1992). A consumer test with four scab-resistant cultivars showed that these were acceptable to the American consumer (Durner et al., 1992). Some of the first scab-resistant cultivars were characterised by a taste panel to have insufficient general eating quality (Grauslund, 1997a), although Danish consumers have a very positive attitude towards the new scab-resistant cultivars (Grauslund, 1997a,b; Kühn, 1998). The long lifetime of an apple orchard makes the decision of which cultivar to plant for future production very critical for the fruit grower, and the existence of many new, unfamiliar cultivars makes this decision increasingly difficult. Knowledge about the sensory quality will facilitate the choice among the many scab-resistant cultivars for both the fruit grower and the consumer. The aim of the present paper is to describe the sensory quality of 22 scab-resistant cultivars. Investigations were performed in Octo- ber, November and December to obtain information about the influence of short-term storage on the sensory quality of scab-resistant cultivars.

\section{Material and methods}

\subsection{Fruits}

Twenty-two scab-resistant apple cultivars were grown in the Experimental Orchard situated in Årslev, Denmark. Trees were grown on M9 rootstocks using integrated pest and disease management. Fruits were sampled from eight young trees (age 3-5 years) per cultivar. To obtain fruit suitable for storage, picking commenced when ripening had started, before optimal eating quality was attained. An expert panel consisting of three people established the picking dates of the scab-resistant cultivars based on their experience of

Table 1

Sampling dates for sensory analysis, abbreviations used in figures, country of origin and harvest date for 24 apple cultivars

\begin{tabular}{|c|c|c|c|c|c|c|}
\hline Cultivar & $\begin{array}{l}\text { October } \\
1-6\end{array}$ & $\begin{array}{l}\text { November } \\
11-15\end{array}$ & $\begin{array}{l}\text { December } \\
13-15\end{array}$ & Abbreviation & Origin & Harvest date \\
\hline 'Redfree' & $\mathrm{x}$ & & & Red & USA & 31 August \\
\hline 'Witos' & $\mathrm{x}$ & & & Wit & USA & 6 September \\
\hline 'Aroma'a & $\mathrm{x}$ & $\mathrm{x}$ & $\mathbf{x}$ & Aro & Sweden & 6 September \\
\hline ‘Prima' & $\mathbf{x}$ & $\mathrm{x}$ & $\mathrm{x}$ & Prima & USA & 7 September \\
\hline 'Realka' & $\mathrm{x}$ & $\mathrm{x}$ & $\mathrm{x}$ & Rea & Germany & 7 September \\
\hline 'Retina' & $\mathrm{x}$ & $\mathbf{x}$ & $\mathrm{x}$ & Ret & Germeny & 7 September \\
\hline 'Sawa' & $\mathrm{x}$ & $\mathbf{x}$ & $\mathrm{x}$ & Saw & Poland & 13 September \\
\hline 'Dayton' & $\mathrm{x}$ & $\mathrm{x}$ & $\mathrm{x}$ & Day & USA & 13 September \\
\hline 'Primicia' & $\mathrm{x}$ & $x$ & $\mathrm{x}$ & Primi & Brazil & 15 September \\
\hline 'Vanda' & $\mathrm{x}$ & $\mathrm{x}$ & Van & Czech Republic & 20 September & \\
\hline 'Initial' & $\mathrm{x}$ & $\mathrm{x}$ & Ini & France & 21 September & \\
\hline 'Elstar’'a & $\mathrm{x}$ & $\mathrm{x}$ & Els & Holland & 21 September & \\
\hline 'Merlijn' & $\mathrm{x}$ & $\mathrm{x}$ & Mer & Belgium & 22 September & \\
\hline 'McShay' & $\mathrm{x}$ & $\mathbf{x}$ & $\mathrm{McS}$ & USA & 27 September & \\
\hline 'Rajka' & $\mathbf{x}$ & $\mathrm{x}$ & Raj & Czech Republic & 28 September & \\
\hline 'Rubinola' & $\mathbf{x}$ & $\mathrm{x}$ & Rub & Czech Republic & 30 September & \\
\hline 'Rosana' & $\mathrm{x}$ & $\mathrm{x}$ & Ros & Czech Republic & 4 October & \\
\hline 'Otava' & $\mathrm{x}$ & $\mathrm{x}$ & Ota & Czech Republic & 11 October & \\
\hline 'Saturn' & $\mathrm{x}$ & $\mathrm{x}$ & Sat & UK & 12 October & \\
\hline 'Enterprise' & & $\mathrm{x}$ & Ent & USA & 12 October & \\
\hline 'Topaz' & & $\mathrm{x}$ & Top & Czech Republic & 13 October & \\
\hline 'Ecolette' & & $\mathrm{x}$ & Eco & Holland & 13 October & \\
\hline 'Resista' & & $\mathrm{x}$ & Res & Czech Republic & 18 October & \\
\hline 'Delorina' & & $\mathrm{x}$ & Del & France & 25 October & \\
\hline
\end{tabular}

\footnotetext{
${ }^{\text {a }}$ Reference samples (scab-susceptible cultivars).
} 
Table 2

Description of sensory attributes of apples

\begin{tabular}{|c|c|c|}
\hline & Attribute & Description \\
\hline \multirow[t]{3}{*}{ Chew } & Crispness & $\begin{array}{l}\text { Intensity of sound } \\
\text { produced when biting } \\
\text { and chewing once }\end{array}$ \\
\hline & Hardness & $\begin{array}{l}\text { Intensity of force } \\
\text { required when biting } \\
\text { with front teeth }\end{array}$ \\
\hline & Firmness & $\begin{array}{l}\text { Intensity of force } \\
\text { required for chewing } \\
\text { with molars }\end{array}$ \\
\hline \multirow[t]{9}{*}{ When chewing } & Juiciness & $\begin{array}{l}\text { Intensity of moisture } \\
\text { released when } \\
\text { chewing }\end{array}$ \\
\hline & Mealiness & $\begin{array}{l}\text { Intensity of granular } \\
\text { dry structure }\end{array}$ \\
\hline & Skin toughness & $\begin{array}{l}\text { Intensity of skin } \\
\text { residual in the mouth } \\
\text { before swallowing }\end{array}$ \\
\hline & Sweetness & $\begin{array}{l}\text { Intensity of sweet } \\
\text { taste }\end{array}$ \\
\hline & Sourness & Intensity of sour taste \\
\hline & Unripe flavour & $\begin{array}{l}\text { Intensity of astringent } \\
\text { taste/sense }\end{array}$ \\
\hline & Apple flavour & $\begin{array}{l}\text { Intensity of apple } \\
\text { flavour }\end{array}$ \\
\hline & $\begin{array}{l}\text { Perfumed } \\
\text { flavour }\end{array}$ & $\begin{array}{l}\text { Intensity of } \\
\text { perfumed/aromatic } \\
\text { flavour }\end{array}$ \\
\hline & Overripe flavour & $\begin{array}{l}\text { Intensity of negative } \\
\text { flavour }\end{array}$ \\
\hline $\begin{array}{l}\text { After } \\
\text { swallowing }\end{array}$ & $\begin{array}{l}\text { Duration of } \\
\text { apple flavour }\end{array}$ & $\begin{array}{l}\text { Time until the apple } \\
\text { flavour disappears }\end{array}$ \\
\hline
\end{tabular}

determining optimal harvest dates from internal quality of fruits. The internal quality was evaluated by eating the fruits. When a fruit is picked, the ripening continues but at a different rate for different cultivars, and so termination of storage life differs for different cultivars. The fruits were stored at $3.5^{\circ} \mathrm{C}$ in an ambient atmosphere. Before sensory evaluation, fruits were equilibrated to room temperature for $24 \mathrm{~h}$.

The cultivar names and origins are given in Table 1. The cultivars 'Aroma' and 'Elstar' were used as sensory references. In Denmark, the cultivar 'Aroma' is significant for the autumn season, and 'Elstar' is on the market in late autumn to winter (Kühn, 2000); neither is scab-resistant.
Investigations were performed in three periods: (1) 1-6 October, (2) 11-15 November and (3) 13-15 December 1999. Owing to different storage characteristics and picking dates, some cultivars were investigated once, twice or three times. An overview is given in Table 1 .

\subsection{Sensory evaluation}

\subsubsection{Sensory training}

A 10-member panel (eight females/two males, aged 25-52 years) was recruited from the staff at The Danish Institute of Agricultural Sciences. The requirements for selection were availability and motivation to participate, and screening for ability to discriminate odours and tastes (Jellinek, 1985; ISO, 1991). A $4 \mathrm{~h}$ vocabulary development session was carried out, and descriptions of the attributes are found in Table 2. In the first bite, crispness and hardness were evaluated. During chewing, texture, taste and aroma attributes were evaluated. The texture was evaluated using the terms: crispness, hardness, firmness, mealiness, juiciness, and skin toughness. The taste and flavour were described by attributes such as sweetness, sourness, unripe flavour, apple flavour, perfumed flavour, overripe flavour and duration of apple flavour after swallowing. The panel was trained by profiling six apple cultivars ('Aroma', 'James Grieve', 'Vista Bella', 'Delcorf', selection no. 9P-15-30, and selection no. 11W-16-61) covering the variation in most of the attributes. The training was performed in six replications and assessors were evaluated for reliability and validity (Meilgaard et al., 1991).

\subsubsection{Sensory test}

Eight scab-resistant apple varieties were evaluated in October, 18 in November and 20 in December (Table 1). The cultivars 'Aroma' (October, November, and December) and 'Elstar' (November, December) were used as reference samples and were served for each assessor before the sensory evaluation with given marks on the scale for each attribute for each storage time. These reference scores were obtained by consensus between training sessions scores and panel leader evaluation. For each storage time, a panel of 10 


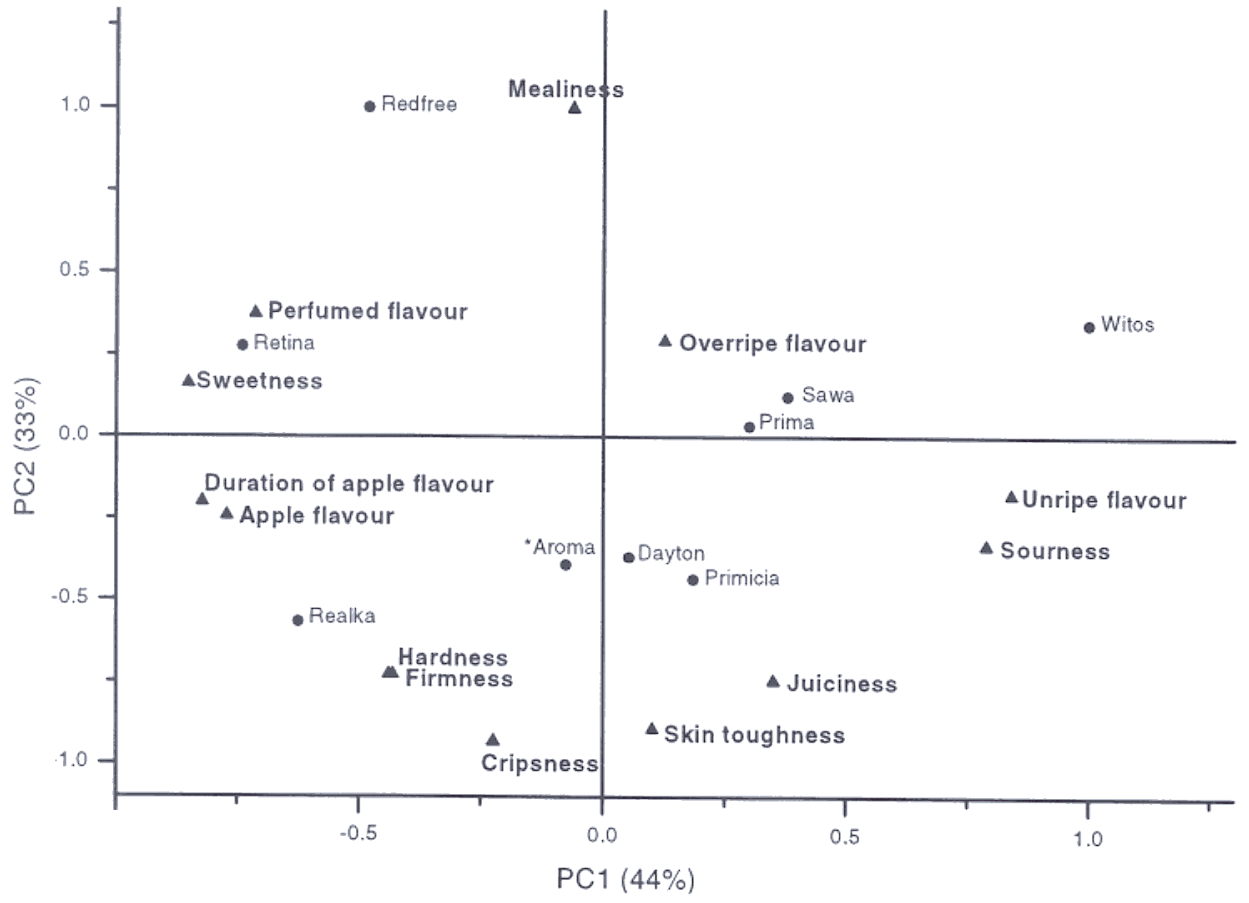

Fig. 1. Bi-plot (loading and scores) of PC1 and PC2 from a PCA model with sensory data for nine cultivars evaluated at the beginning of October 1999.

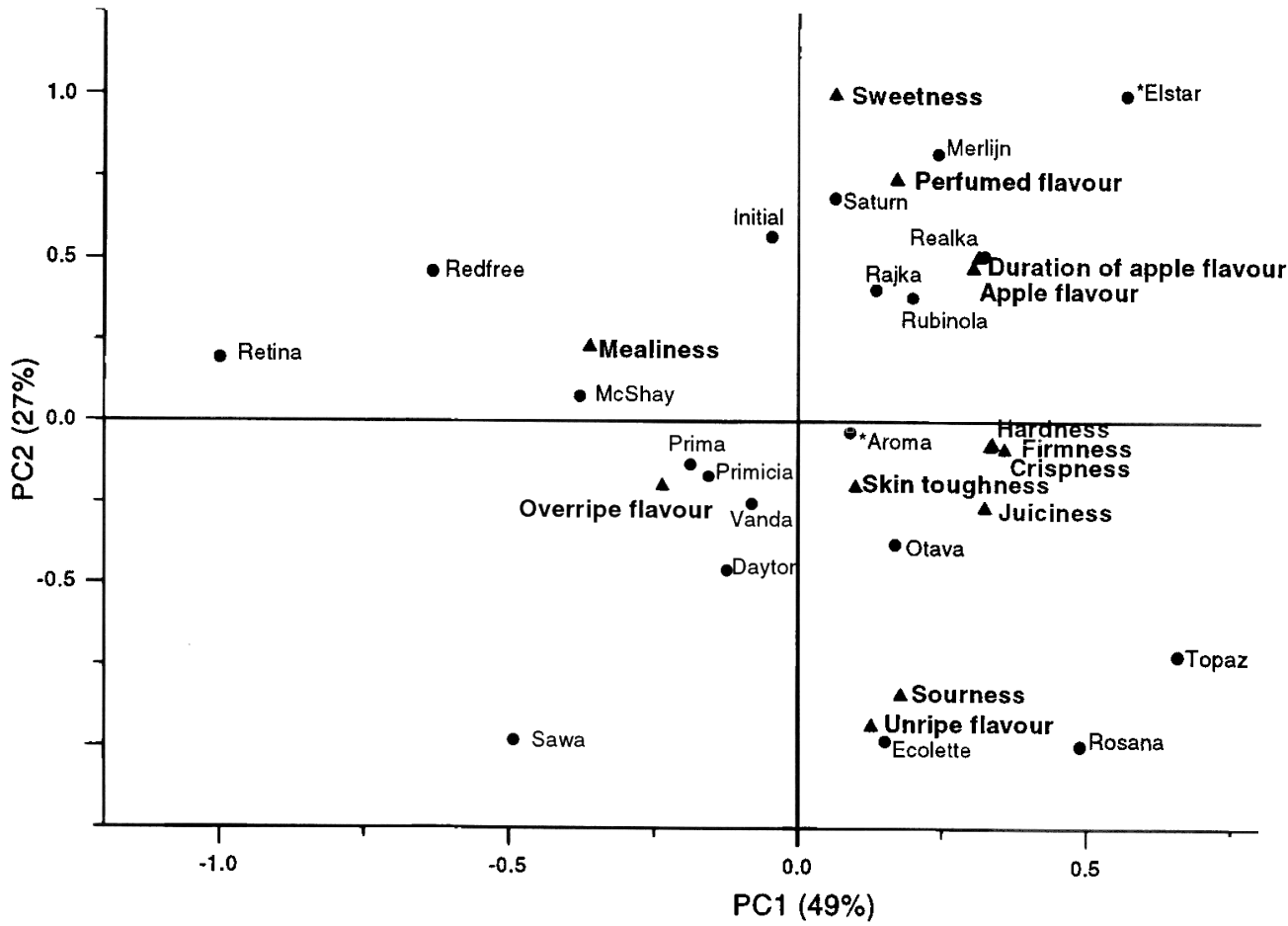

Fig. 2. Bi-plot (loading and scores) of PC1 and PC2 from a PCA model with sensory data for cultivars evaluated mid-November 1999. 


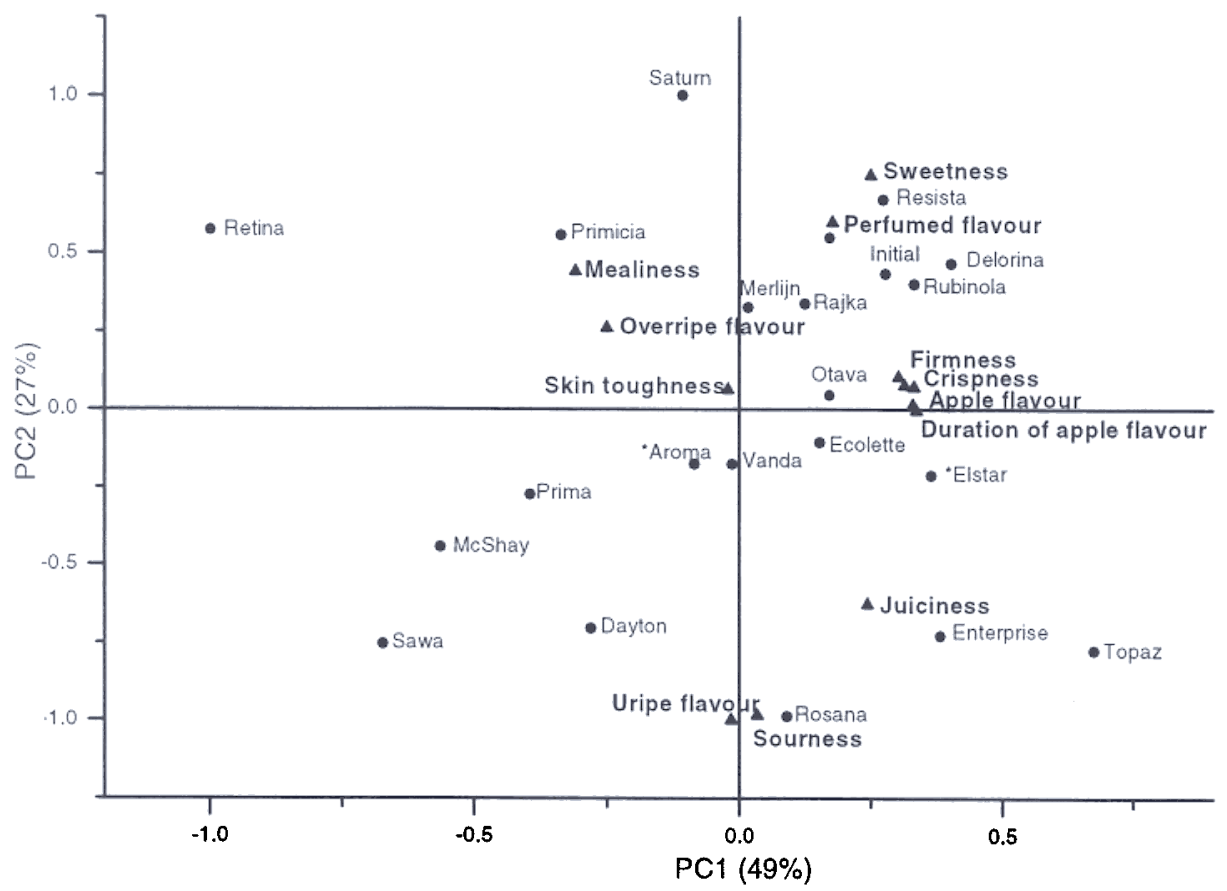

Fig. 3. Bi-plot (loading and scores) of PCl and PC2 from a PCA model with sensory data for 22 cultivars evaluated mid-December 1999.

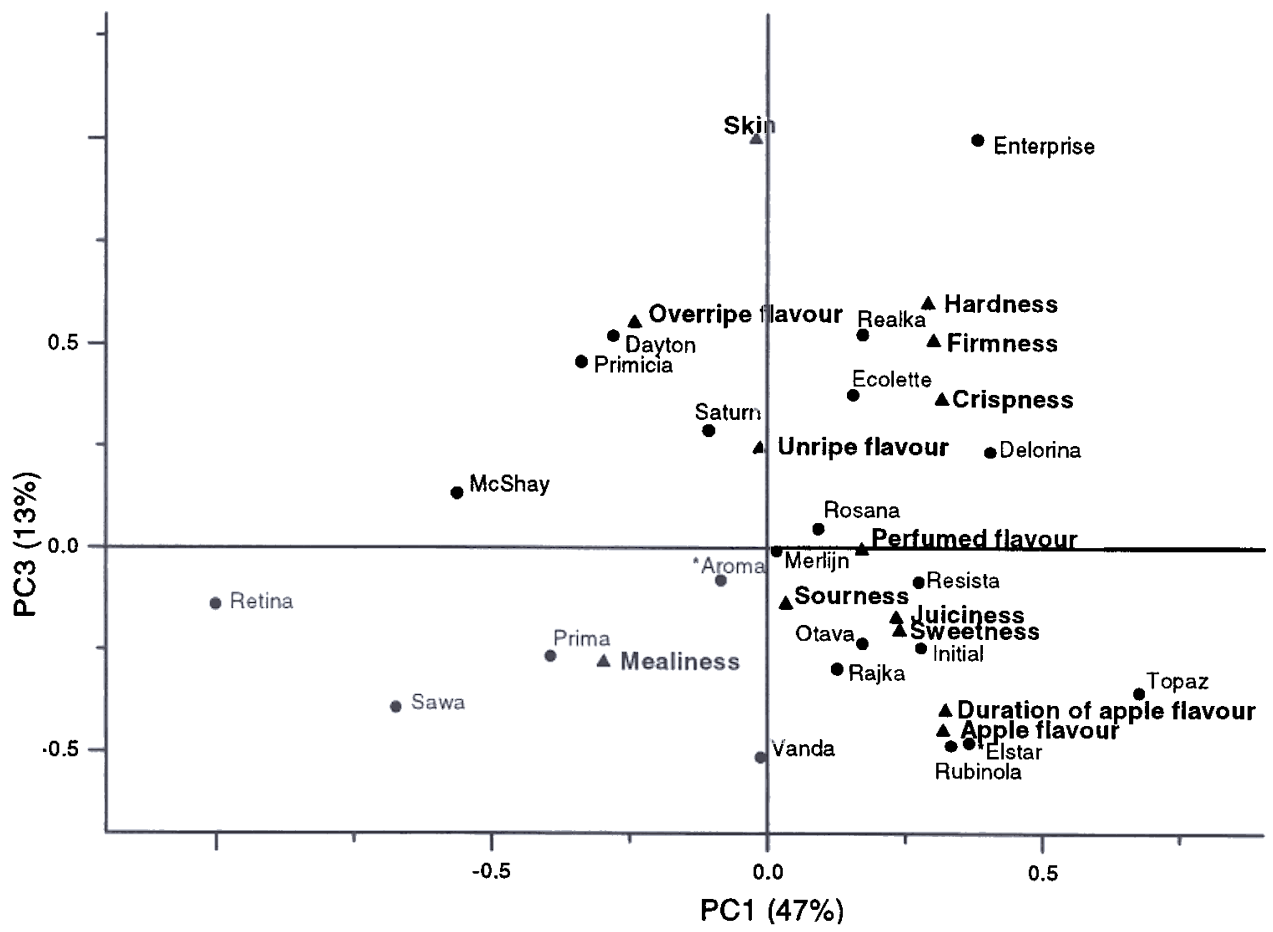

Fig. 4. Bi-plot (loading and scores) of PC and PC3 from a PCA model with sensory data for 22 cultivars evaluated mid-December 1999. 
assessors evaluated all samples. In October, cultivars were evaluated in one session, and in November and December, two and three sessions were used to evaluate all cultivars. The sensory analyses were performed in three replications with a total randomisation of cultivars and replications. For each session, three apples were quartered, one quarter being served for each assessor. Samples were served in a random order on white dishes coded with a three-digit random number. Samples were served with skin to allow determination of skin toughness. In a preliminary evaluation (unpublished), skin toughness was found to be more pronounced in scab-resistant apples and may have been an important attribute in profiling their sensory quality. Assessors were asked to rinse their mouths before a new sample was evaluated, and dry biscuits were available. The assessors evaluated the 13 sensory texture, taste and flavour attributes for each sample using a $15 \mathrm{~cm}$ unstructured line scale with anchor points 'none' on the left-hand side and 'very much' on the right-hand side.

\subsection{Statistical analysis}

The sensory quality of each apple cultivar was studied by multivariate Principal Component Analysis, PCA (Unscrambler, version 7.5, CAMO, Trondheim, Norway) and ANOVA, SAS Version 6.12 (1996, Cary, USA). PCA was used to extract the most important information in a number of Principal Components (PCs) ranked in decreasing order of importance according to the decreased amount of explained variation. The PCA permits a study of all sensory variables in one analysis and decomposes the relevant information in a few PCs. Investigations were performed for all storage times to study the influence of storage on quality of each

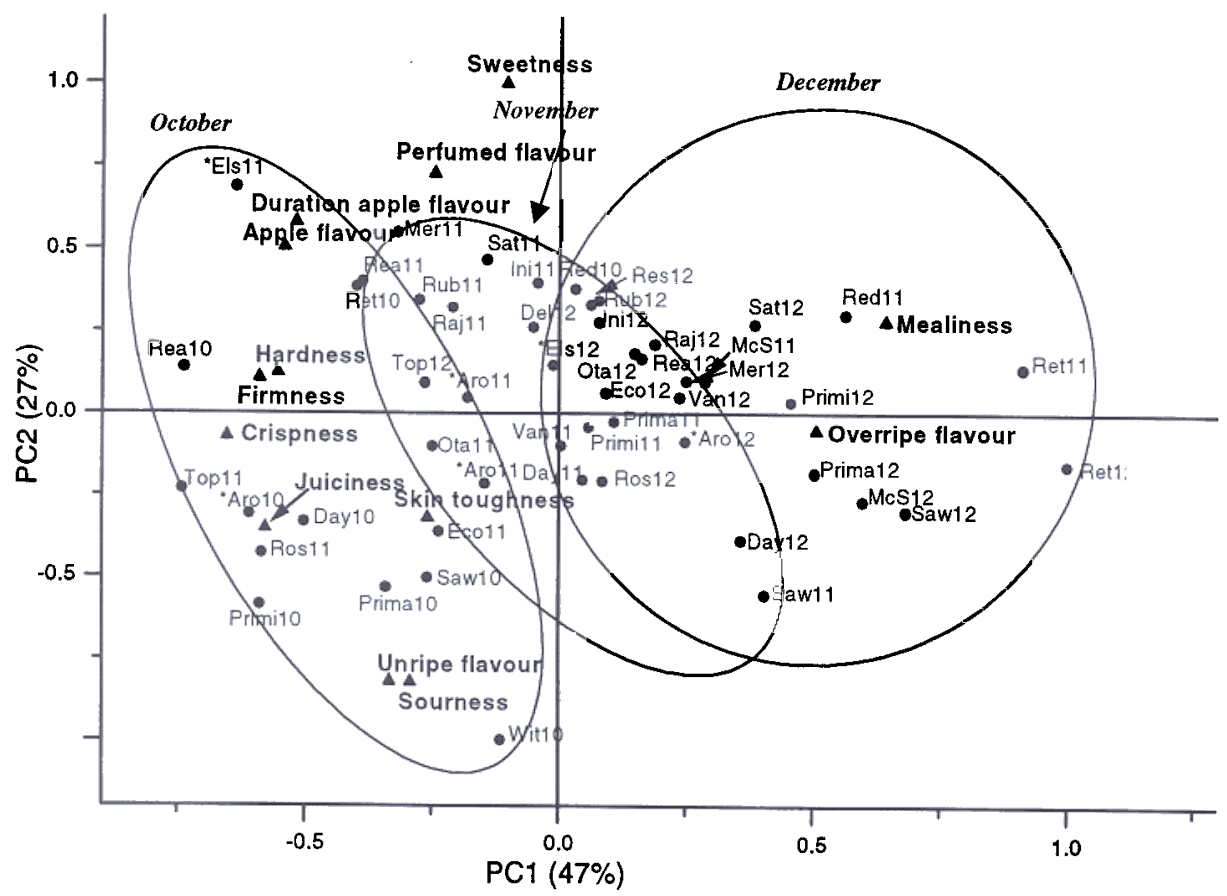

Fig. 5. Bi-plot (loading and scores) of PC1 and PC2 from a PCA model with sensory data for nine to 22 scab-resistant apple cultivars evaluated at the beginning of October (extension 10), mid-November (extension 11) and mid-December (extension 12) 1999. Sample abbreviations given in Table 1. 
apple cultivar. Analysis on each storage time was performed to investigate cultivar differences within a given storage time.

\section{Results and discussions}

\subsection{Sensory quality of apple cultivars}

Analysis of variance (ANOVA) indicated significant differences between most cultivars and storage time for each attribute.

To describe the sensory quality of apple cultivars at different times after harvest, the sensory data were analysed for each storage time. The PCA on data from different storage times showed similar types of variation in the sensory profiles. Three significant PCs described $80-90 \%$ of the sensory variation for the 8 October, 18 November and 20 December apple cultivars by a texture variation (mealiness versus hardness, firmness, crispness and juiciness), a taste/flavour variation (unripe flavour and sourness versus sweetness and perfumed flavour) and a skin toughness/overripe flavour versus an apple flavour variation (Figs. 1-3), corresponding to the results obtained by Zerbini et al. (1999). In October, the taste variation (Fig. 1, $\mathrm{PC} 1)$ was more significant than the texture variation (PC2) in contrast to results from November and December (Figs. 2 and 3). It was confirmed that unripe flavour and sourness are most prevalent in cultivars ripening in the early season.

Among the eight cultivars investigated in October, 'Witos', 'Sawa' and 'Prima' were the most unripe and sour cultivars having a low sweetness, low perfumed flavour and low apple flavour (Fig. 1, PC1). When picked prematurely, apples will develop flavour during storage (Stolle et al., 1984), although the production of aromatic compounds will be reduced if the apples are picked at the preclimateric stage (Brackmann et al., 1993; Song and Bangerth, 1996). 'Witos', 'Sawa' and 'Prima' fruit might have been picked too early to ripen during storage. 'Retina' fruit had a high sweetness, high apple and perfumed flavour and low sour and unripe flavour. The lowest juiciness and crispness and highest mealiness were found for 'Redfree' fruit (Fig. 1, PC2), which is not surprising considering it was the first picked cultivar (Table 1) and is described as a summer cultivar with a maximum storage life of up to 2 months (Williams et al., 1981). In Northern Germany, 'Redfree' fruit retains quality in cold storage to the end of October (Stehr, 1997). The most important characteristic for 'Realka' fruit was the very firm and crispy texture (Fig. 1). As 'Dayton' and 'Primicia' fruit had a sensory profile very similar to 'Aroma' fruit, these scab-resistant cultivars may be potential apples for consumption in October. The high intensity of apple flavour and firmness of 'Retina' and 'Realka' fruit also made these cultivars suitable for consumption in October.

In November, 18 cultivars were analysed (Table 1). 'Redfree', 'Retina' and 'McShay' were characterised as the mealiest cultivars with low crispness and firmness (Fig. 2, PC1). The cultivars 'Merlijn', 'Saturn', 'Initial', 'Realka', 'Rajka' and 'Rubinola' were found to resemble the reference samples 'Elstar' and 'Aroma' most and were considered to be the most relevant scab-resistant cultivars in November.

The storability of most scab-resistant cultivars is not expected after December. Therefore, the study of the sensory profile of 20 apple cultivars was terminated in December (Table 1). As in November, 'Rosana' and, to some extent, 'Sawa', 'Topaz' and 'Dayton' were found, in December, to be the sourest unripe tasting cultivars and 'Saturn' the least sour cultivar (Fig. 3, PC2). The late mature cultivars 'Delorina' and 'Resista', evaluated only in December, had a sweet, perfumed character with apple flavour, and the late maturing cultivar 'Enterprise' was sour. In December, 'Otava', 'Ecolette', 'Rajka', 'Rubinola', 'Delorina', 'Initial' and 'Resista' and 'Topaz' had a sensory quality close to the reference cultivar 'Elstar' and may be suitable for consumption.

A significant characteristic of some of the scabresistant apple cultivars was the presence of a tough skin that remained in the mouth, even after thorough chewing. Residual skin on swallowing is a negative characteristic. For all storage times, the skin toughness was highly correlated to overripe flavour and negatively correlated to apple flavour (PC 3 in Fig. 4). 
(A)

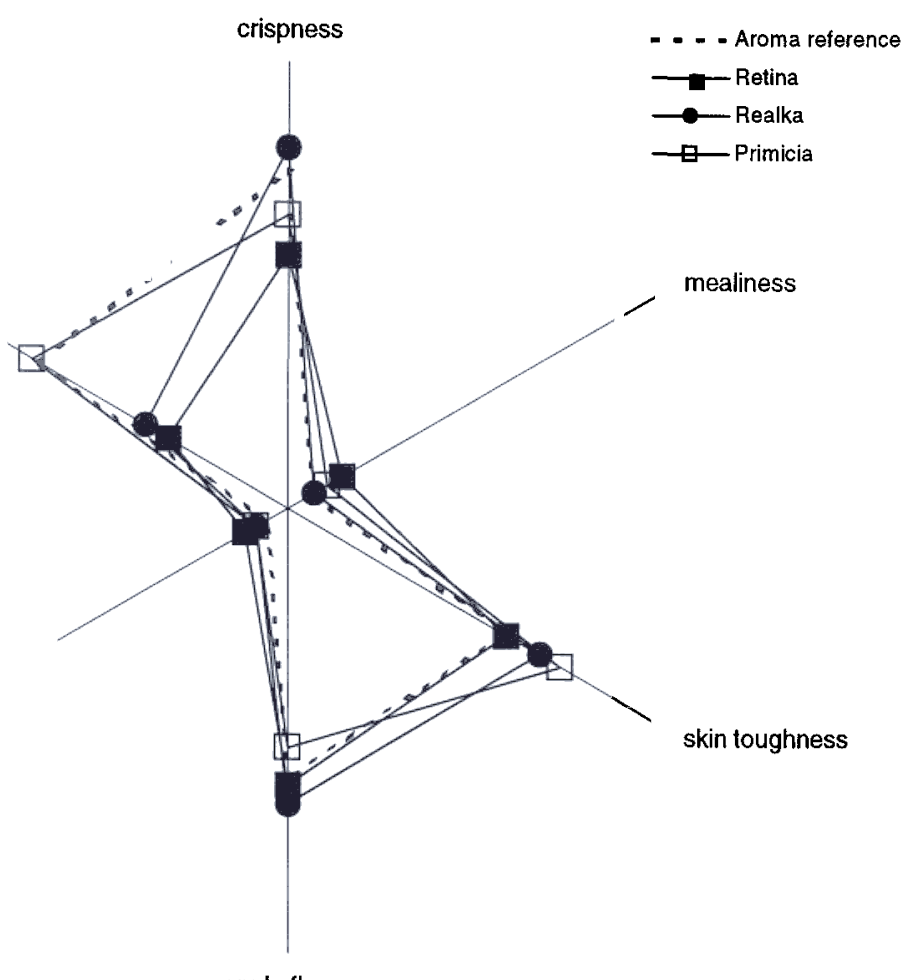

(B)

apple flavour

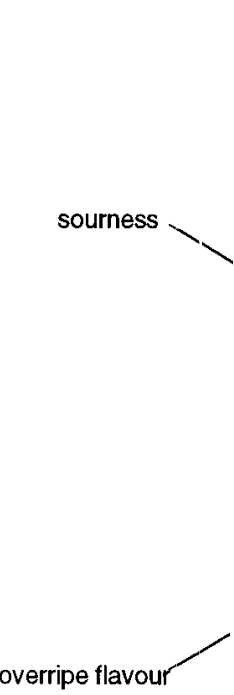

crispness
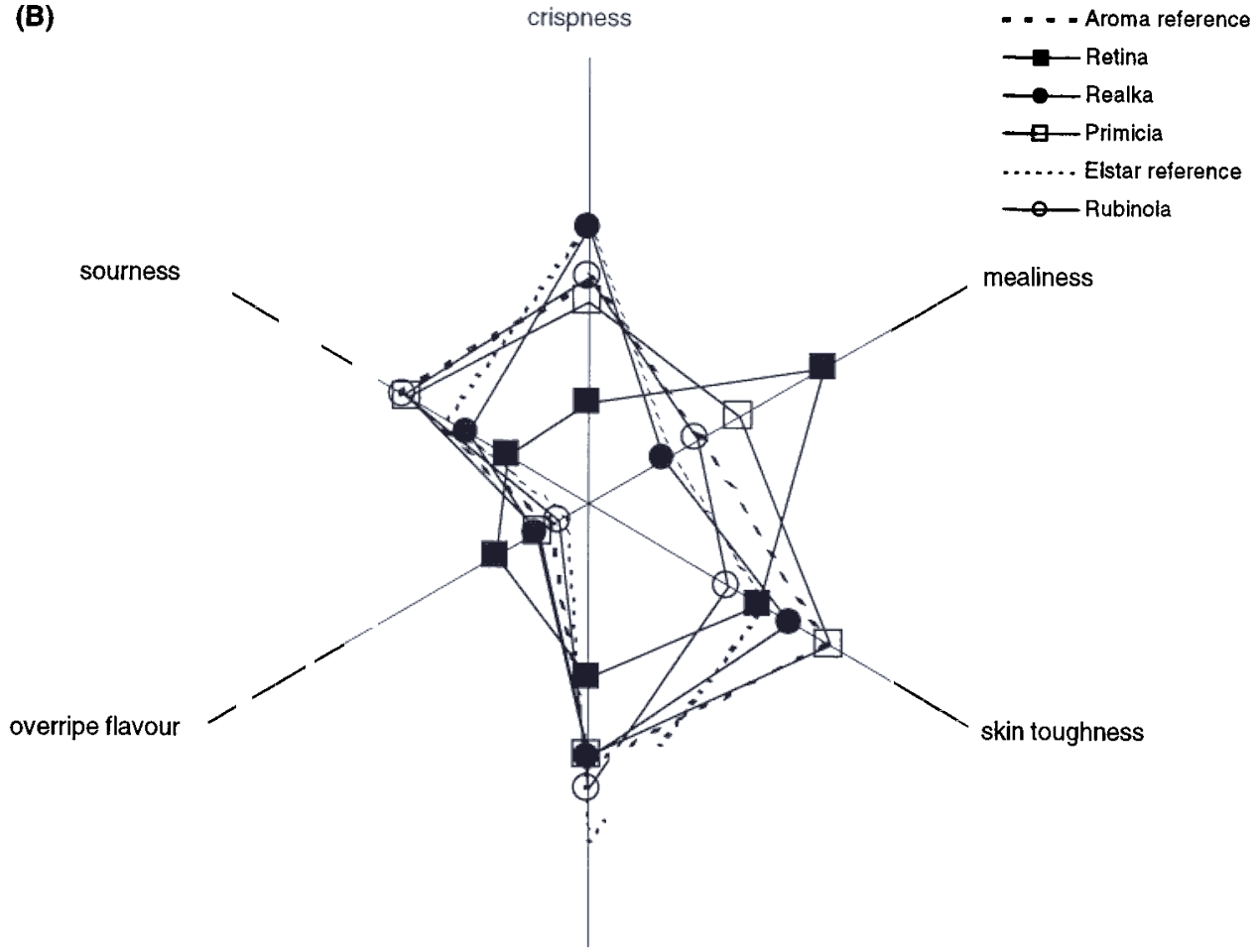

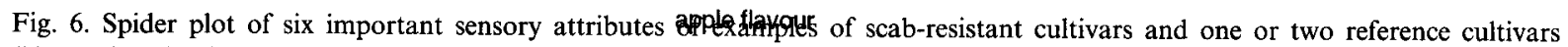
('Aroma' and 'Elstar') in October (A), November (B) and December (C). 
(C)
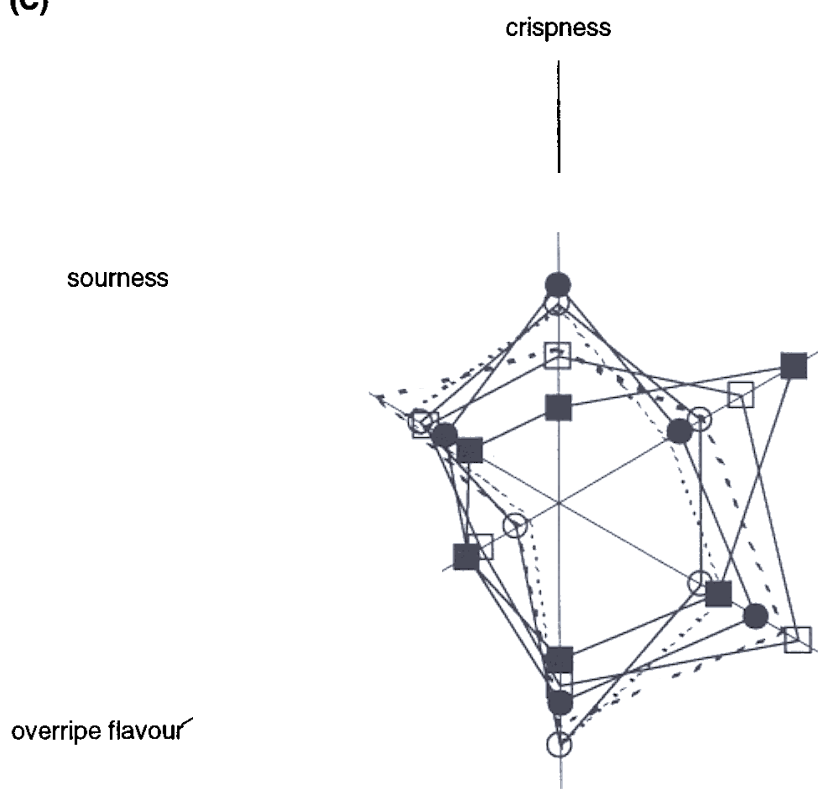

apple flavour

Fig. 6. (Continued)

\subsection{Changes in sensory quality of apple cultivar:} during storage

Analysis of the sensory data from all storage times yields information about the major sensory changes during storage. The first PC (47\%) illustrated a texture/overripe flavour variation followed by a flavour and taste PC $(27 \%)$ variation between apples (Fig. 5). Apple cultivars with a high mealiness had a highly overripe flavour and were low in hardness, crispness, juiciness and firmness. The texture variation definitely resulted from a combination of an effect of storage and cultivar differences, since apples increased in mealiness and decreased in hardness, crispness, firmness and juiciness when cold-stored (Fig. 5, PC1). This change in texture during storage was most pronounced for 'Retina' fruit, which was hard and crispy in October and mealy in November and December (Fig. 6). Along with an increase in mealiness, an increase in overripe flavour occurred with prolonged storage, presumably provoked by an advancing of fruit senescence, which has been shown to contribute to accumulation of components with an atypical fruit taste (Blanpied et al., 1968).

The variation in taste and flavour (Fig. 5, PC2) of the apples was primarily due to cultivar differences and, to a lesser extent, to the effect of storage. The production of aroma compounds is genetically controlled but modified by external and physiological factors as well as maturity (Brackmann et al., 1993). During storage, production of apple aroma components shifts from production of 'fresh green flavour' (due to aldehydes) towards production of more perfumed or fruity aromatic components (due to esters) (Kaack, 1977). Most of the cultivars decreased in sourness and unripe flavour towards a sweeter and more perfumed flavour with increasing storage time (Fig. 5, PC2). An increase in sweetness and a decrease in acidity during cold storage has been demonstrated for several cultivars (Watada et al., 1981; Tu et al., 1997). The results signify that the 
cultivars 'Retina', 'McShay', 'Saturn' and 'Dayton' do not retain quality well during storage since they develop an overripe flavour and a mealy texture with less sweetness and apple flavour. An example of the differences in sensory profiles of the two reference cultivars 'Aroma' and 'Elstar', two highpotential cultivars 'Realka' and 'Rubinola' and two low-potential cultivars 'Retina' and 'Primicia' in October, November and December is presented in Fig. 6. In October, the profiles of 'Retina', 'Realka' and 'Primicia' are very similar to 'Aroma', except for differences in sourness (Fig. 6A). In November, larger differences in sensory profiles are observed in all attributes (Fig. 6B). The change in sensory quality of 'Retina' illustrates the poor storability of this cultivar. In November and December (Fig. 6B and C), 'Primicia' had a high skin toughness, mealiness and sourness and low apple flavour and crispness compared with the reference cultivars and therefore must be considered as a low-potential cultivar. 'Elstar' and 'Rubinola' and, to some extent, 'Realka' were very similar as all had a very high apple flavour and crispness, low skin toughness, mealiness and overripe flavour. As 'Rubinola' and 'Realka' fruit were of a similar eating quality to that of 'Elstar' fruit, they could be considered as alternative cultivars. Minor differences in sensory quality among cultivars were observed in December, however, and 'Elstar' and 'Rubinola' had sensory profiles associated with a higher eating quality.

\section{References}

Blanpied, G.D., Smock, R.M., Frank, L.C., 1968. Some factors influencing the ethanol content of harvested apple fruits. Am. Soc. Hort. Sci. 92, 748-754.

Brackmann, A., Streif, J., Bangerth, F., 1993. Relationship between a reduced aroma production and lipid metabolism of apples after long-term controlled-atmosphere storage. J. Am. Soc. Hortic. Sci. 118, 243-247.

Crosby, J.A., Janick, J., Pecknold, P.C., Korban, S.S., O'Connor, P.A., Ries, S.M., Goffreda, J., Voordeckers, A., 1992. Breeding apples for scab resistance: 1945-1990. Fruit Var. J. 46, 145-166.

Durner, E.F., Dean, F.P., Goeffreda, J.C., 1992. Low-input apple production systems: consumer acceptance of disease- resistant cultivars. HortScience 27, 177-179.

Granger, R.L., Khanizadeh, S., Fortin, J., Lapsley, K., Meheriuk, M., 1992. Sensory evaluation of several scab-resistant apple genotypes. Fruit Var. J. 46, 75-79.

Grauslund, J., 1997a. Hvordan smager skurvresistente aeblesorter? Frugt og Baer 26, 16-17.

Grauslund, J., 1997b. Redfree, Witos og Retina smager godt. Frugt og Baer 26, 208-209.

Greene, D., 1998. Promising high quality apples evaluated in New England. Fruit Var. J. 52, 190-199.

ISO, 1991. Sensory Analysis — General Guidance for the Selection, Training and Monitoring of Assessors - Part 1: Selected Assessors, pp. 1-15.

Jellinek, G., 1985. Theory and Practice. In: Jellinek, G. (Ed.), Sensory Evaluation of Food. Ellis Horwood, Chichester, UK, pp. 39-111.

Kaack, K., 1977. Quatitative and qualitative aroma analysis of apple products. Tidsskrift for Planteavl 81, 139-147.

Kellerhals, M., Goerre, M., Krebs, C., 1998. Schorfresistente Apfelsorten-Qualität und Leistung. Obstbau 23, 410-414.

Kühn, B.F., 1998. Skurvresistente aebler smager godt. Frugt og Baer 27, 128-130.

Kühn, B.F., 2000. Sortsliste for aeble og paere 2000. Frugt og Baer 29, 64-65.

Meilgaard, M., Civille, G.V., Carr, B.T., 1991. Sensory Evaluation Techniques: Selection and Training of Panel Members, second ed. CRC Press, Boca Raton, FL, pp. $147-151$.

Song, J., Bangerth, F., 1996. The effect of harvest date on aroma compound production from 'Golden Delicious' apple fruit and relationship to respiration and ethylene production. Postharvest Biol. Technol. 8, 259-269.

Stehr, R., 1997. Schorfresistente Apfelsorten. Erfahrungen aus Norddeutschland, Teil 2. Obstbau 22, 490-495.

Stolle, G., Reichel, M., Schmidt, G., 1984. Der Einfluss von Erntetermin, Fruchtgrössse, Lagerungsverfahren und Lagerungsdauer auf den Gesmack zweier Apfelsortern. I Die Frucht zum Erntetermin. Akademie der Landwirtschaftswissenschaften der DDR Archiv Gartenbau 32, 139-149.

Tu, K., Waldron, K., De Barsy, T., De Baerdemaeker, J., 1997. Effect of picking time and storage conditions on 'Cox's Orange Pippin' apple texture in relation to cell wall changes. J. Hort. Sci. 72, 971-980.

Watada, A.E., Abbott, J.A., Hardenburg, R.E., Lusby, W., 1981. Relationships of apple sensory attributes to headspace volatiles, soluble solids, and titrable acids. J. Am. Soc. Hort. Sci. 106, 130-132.

Williams, E.B., Janick, J., Emerson, F.H., Dayton, D.F., Hough, L.F., Bailey, C., 1981. 'Redfree' apple. HortScience 16, 798-799.

Zerbini, P.E., Pianezzola, A., Grassi, M., 1999. Poststorage sensory profiles of fruit of five apple cultivars harvested at different maturity stages. J. Food Qual. 22, 1-17.

Zimmer, J., 1999. Prüfung von schorfresistenten Apfelsorten an der SLVA Ahrweiler. Erwerbsobstbau 41, 185-191. 